\title{
The Effect of Folk Dance Performance with and Without Costume on Heart Rate of the Girls within the Age Group of 9-11
}

\author{
Gamze Erikoğlu Örer ${ }^{1}$, Gözde Algün Doğu ${ }^{2}$ \\ YIldırIm Beyazıt University, Faculty of Health Sciences, Sport Sciences Department ${ }^{1,2}$
}

\begin{abstract}
This study has been planned in order to evaluate the effect of the folk dance performance with and without costume on heart rate of the girls within the age group of 9-11 after folk dance exercises performed for 12 weeks. 16 female students has participated in measurements of the research with age, height, body weight and BMI average respectively $10.06 \pm 0.77,1.38 \pm 0.07,33 \pm 7.83,17.10 \pm 3.40$. The exercises were performed for 2 hours a day and 4 days a week by the students after school and 8 dances peculiar to Bilecik Region were taught. At the end of 8 weeks, as the students could not wear any device on them during the competition, their heart rate was recorded with polar watches during 8 minute rehearsals performed with and without costume at the stage performance level. As a result of the study, when the maximal and average heart rate values of the group measured with and without costume were compared, statistically significant differences were found $(p<0,05)$. As a result; it has been observed that the folk dance performances carried out in two different techniques have an effect on the heart rate. The athletes' body weights and body temperatures increased due to the weight and texture of the costumes. As this effect caused them to expand more energy during the performance, it is considered that it causes the increase in body temperature and at the same time in heart rate.

Keywords: folk dance, heart rate, costume
\end{abstract}

\section{Introduction}

Turkish folk dance is a product of the folk culture that includes the history, geography and climate structure, music tradition, clothing, jewelry and the life style of the people of the region to which it belongs. In accordance with its features, the folk dances that appeal to the eye, ear and emotions, at the same time, have to use staging techniques in order to be able to exhibit completely its own unique beauty, rich steps, live music and colorful clothes at the stage. One of these techniques is the phenomenon of "costume", a very important ring of a complicated phenomenon, called the performing arts. It is the general name given to the entire garment which has a very important place especially in visual arts (performing arts such as theatre, cinema ... etc.). "Consuetudo", meaning "tradition" in Latin, is transmitted to Italian and French in the eighteenth century, first as an artistic term, meaning "traditional clothing worn on the stage during the period when it was staged" [1].

Costumes are considered as an element that assists the player to perform his or her duties. The costume is a phenomenon that accompanies the dances of the region. The costume is also considered to have contributions to the player's movements and attitude, and is assumed to increase the player's visual appearance [2]. Heart rate is defined as the number of times the heart beats per minute [3]. The number of heart beats is affected by various factors. These are the duration of the exercise, the physical fitness, age, sex, body size, posture, feelings, excitement, body heat, environmental factors, psychological factors, nutrition, smoking and genetic structure. The heart rate constantly changes throughout the day due to these factors. It varies from person to person [4]. In this study, starting from all this information, the effects of folk dance performance with and without costume on heart rate were examined and significant differences were found. The weight of the costumes, the excitement of the competition and the different rhythms stemming from the dance structure increased the body temperature of the athletes, as well as their body weights. As this effect also causes athletes to expend more energy during the performance, it is considered that it causes the increase in body temperature and at the same time the increase in heart rate.

\section{Method}

Research Group: 16 female students has participated in measurements of the research with age, height, body weight and BMI average respectively 10.06 $\pm 0.77,1.38 \pm 0.07,33 \pm 7.83,17.10 \pm 3.40$. Enlightened approvals were obtained by giving detailed information about the study to the families and coaches of the female students and themselves. The exercises were performed for 2 hours a day and 4 days a week by the students after school and 8 dances peculiar to Bilecik Region were taught. At the end of 8 weeks, as the students could not wear any device on them during the competition, their heart rate was recorded with polar watches during 8 minute rehearsals performed with and without costume at the stage performance level. 


\section{Data Collection:}

Weight measurement:

For the body weight measurement, TANITA BC 418 body analyzer with an accuracy of $0.1 \mathrm{~kg}$ was used.

\section{Height measurement:}

Their heights were measured with a $0.01 \mathrm{~cm}$ precision stadiometer (Holtain Ltd. UK.).

Body Mass Index (BMI):

It is the body weight divided by the square of the height. (BW. $\mathrm{kg} /$ height $^{2} . \mathrm{cm}$ )

\section{Heart Rate Monitor (HR):}

The heart rate was continuously recorded every second with the heart rate monitor placed on the subjects (Interval of $1 \mathrm{sec}$ ) (Polar V800, Finland).

Analysis of Data: After calculating the average and standard deviation (x, sd), the measurements were determined and the Wilcoxon test was applied to the dependent groups through the SPSS 22 program and the significance level was accepted as $\mathrm{p}<0.05$.

\section{Findings}

Table 1: Anthropometric data of the Group

\begin{tabular}{ccccc}
\hline $\begin{array}{c}\text { Group } \\
(\mathbf{n = 1 6})\end{array}$ & $\begin{array}{c}\text { Height } \\
(\mathbf{c m})\end{array}$ & $\begin{array}{c}\text { Body Mass } \\
\text { Index } \\
(\mathbf{B M I})\end{array}$ & $\begin{array}{c}\text { Age } \\
(\text { year })\end{array}$ & $\begin{array}{c}\text { Body weight } \\
(\mathbf{B W}-\mathbf{k g})\end{array}$ \\
\hline & $1,38 \pm 0,07$ & $17,10 \pm 3,40$ & $10,06 \pm 0,77$ & $33 \pm 7,83$ \\
\hline
\end{tabular}

Table 2: Maximal and average heart rate values of the group with and without costume

\begin{tabular}{ccc} 
& HR-Avg $(\mathbf{n}=\mathbf{1 6})$ & HR-Max $(\mathbf{n}=\mathbf{1 6})$ \\
\hline Without Costume - HR & $125,81 \pm 9,73$ & $151 \pm 13,04$ \\
With Costume - HR & $138,81 \pm 16,53$ & $172,12 \pm 10,92$ \\
$\mathbf{Z}$ & $-2,53$ & $-3,33$ \\
$\mathbf{p}$ & $\mathbf{0 , 0 1 *}$ & $\mathbf{0 , 0 0 *}$ \\
\hline
\end{tabular}

$*(\mathrm{p} \leq 0.05)$

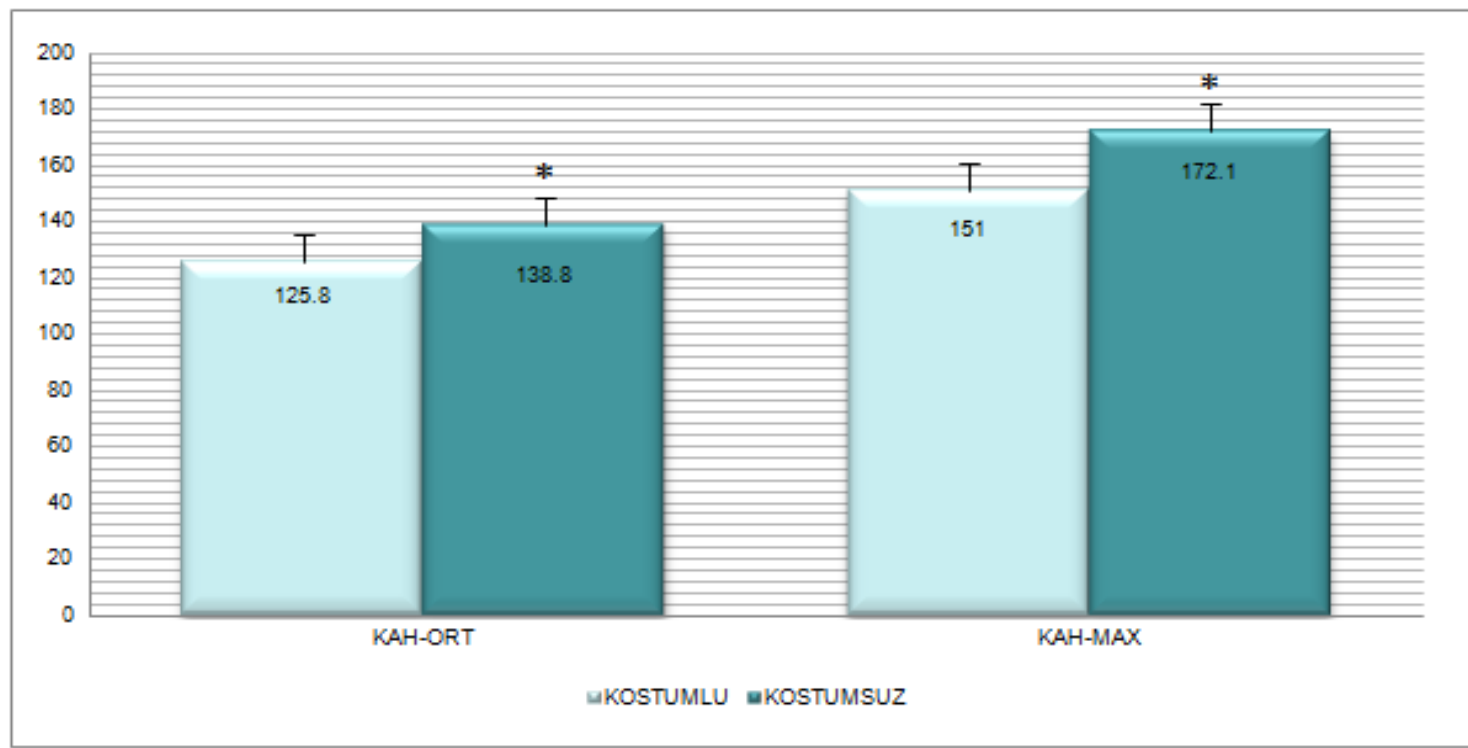

Graphic 1: Maximal and average heart rate values of the group with and without costume

When the maximal and average heart rate values of the group with and without costume are compared, statistically significant differences are found $(\mathrm{p}<0,05)$. 


\section{Discussion And Conclusions}

Folk dance is defined as a "restrained and regular set of movements which reflects the cultural values of the community to which it belongs; expresses an event, happiness, sadness; is based on religion and magic and is performed to music by a single person or in groups [5].

Various movement figures performed in folk dances can create physiological, biochemical and biomotoric changes, causing a certain load on the human organism, depending on the time, performing form and the various periods and rhythms of these figures [5].

When the factors affecting the heart rate, one of the physiological changes, are examined in detail, it is stated that the increase in the body temperature and the increase in the heart rate are directly proportionate to each other. It is also emphasized that as heavy clothing, uncomfortable clothing, or clothing and shoes with inappropriate aerodynamics or hydrodynamic require more effort to expand for the exercise, the heart rate increases $[7,8,9,10,11]$. In this study, which has been conducted in order to examine the effects of the performance with and without costume on the heart rate of the folk dancers, statistically significant differences were found in maximal and average heart rates. Recently, in groups that have started with professional dance troupes and continue; performing new presentations with folk dance figures, the costumes have been designed with completely different purposes than the traditional dress features.

These troupes, who leave their mark on the 2000s, prefer costumes that give them freedom of movement while performing. These troupes especially emphasize that it is sufficient for the costumes chosen to have lines reminiscent of the locality, and that the important point for them is that the costume should not restrict movements [12]. It can be said that during the folk dance performances with and without costume, significant differences are found in the heart rate of the athletes due to the weight of the costumes and accessories.

On the other hand, depending on the emotional patterns (enthusiasm, excitement, etc.), the hormonal level of the person also affects the heart rate. Pre-race anxiety or irritability increases the heart rate due to adrenaline release. Also happiness, excitement, sadness or stresses increase the heart rate $[\mathbf{7}, \mathbf{1 0}, \mathbf{1 3}, \mathbf{1 4}]$. In our study, in parallel with this data, it is considered that the athletes have demonstrated this effect as the increase in the heart rate by getting excited during the performances with costume.

Regarding the exercise, running rhythm, pedal rhythm, stroke rhythm or rowing rhythm at heart rate [7, 15]. It can be said that the various movement figures performed in folk dances can cause changes in HR, depending on the time and performing form and the various periods and rhythms of these figures. For these reasons, significant differences in average and maximal heart rate of the athletes are found in measurement results conducted with and without costume. It is considered that positive effects on the performances with costume will be observed by increasing the strength and durability performances of the folk dancers.

Moreover, it can be said that the increase in HR due to excitement can be controlled by keeping the excitement of the folk dancers at a minimum level through increasing race experiences. Although it is known that it will cause cultural corruption, modernizing and lightening the costumes are considered to cause positive effects on the performances of the folk dancers.

[1]. http://tr.wikipedia.org/wiki/Kost\%C3\%BCm

\section{References}

[2]. Altuntaş, Yener; "Halk Oyunlarımızın Sahnelenmesinde Giysi ile İlgili Problemler", Türk Halk Oyunlarının Sahnelenmesinde Karşılaşılan Problemler Sempozyumu, Kültür ve Turizm Bakanlığı Milli Folklor Araştırma Dairesi Yayınları, Ankara 1987, s.15.

[3]. Günay M. Farklı Kuvvet Antrenman Metotlarının Vücut Kompozisyonuna Etkisi, Gazi Üniversitesi, Sağlık Bilimleri Enstitüsü, Beden Eğitimi ve Spor Anabilim Dalı, Doktora Tezi, Ankara, 1993

[4]. Tamer K. Sporda Fiziksel Fizyolojik Performansının Ölçülmesi ve Değerlendirilmesi, İkinci Baskı, Ankara, Bağırgan Yayınevi, 2000;47-131-132.

[5]. Eroğlu T. Halk Oyunları El Kitabı. İstanbul: Mars Basımevi; 1999.

[6]. Sargın, K. Düzenli Halk Oyunları Egzersizlerine Katılan Bireylerde Halk Oyunlarının Bazı Biyomotorik Ve Fizyolojik Etkilerinin İncelenmesi: Van Örneği.

[7]. FRIEL, J.: Total Heart Rate Training, sf: 21-35,Ulysses Pres, Kanada, (2006)

[8]. GÜNAY, M., CíCiOĞLU İ., Spor Fizyolojisi, Gazi Kitabevi, 205-218, Ankara, (2001).,

[9]. HumidityandHeart Rate (online) (cited 2007 Apr 23). Availablefrom : URL : yapılmaktadır. (FRIEL, J.: Total Heart Rate Training, sf: 21-35, Ulysses Pres, Kanada, (2006)

[10]. GÜNAY, M., CíCíOĞLU İ., Spor Fizyolojisi, Gazi Kitabevi, 205-218, Ankara, (2001).

[11]. HumidityandHeart Rate (online) (cited 2007 Apr 23). Availablefrom :URL : http://sleepdesign.com/dunlo/s_humidity.htm, JANSSEN, P. J. : LactateTreshold Training, Human Kinetics, USA, (2001)

[12]. http://www.fireofanatolia.com/Frontside/roportaj.aspx.

[13]. CULBERT, M.D., TIMOTHY. A PRACTITIONERS GUIDE: Application of theFreeze-Framer Interactive Learning System. 1st ed. BoulderCreek: HeathMath LLC, . (online) (cited 2007 Apr 23). Availablefrom: URL: http://www.warrenwilson.edu/ wellness/heart_rate.shtml.,

[14]. JANSSEN, P. J. : LactateTreshold Training, Human Kinetics, USA, (2001).

[15]. GANONG, F.G. : Review of MedicalPhysiology, 16. Baskı, AppletonandLange, sf: 510-520, Londra, (1993). 